\title{
Evaluation of the injuries caused by Pachycoris torridus (Scopoli, 1772) (Hemiptera: Scutelleridae) in Jatropha curcas (Linnaeus) (Euphorbiaceae) ${ }^{I}$
}

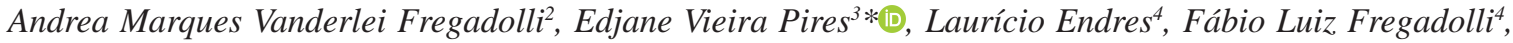 \\ Juan Manuel Perez Ramos ${ }^{5}$, Paulo Vanderlei Ferreira ${ }^{4}$
}

10.1590/0034-737X202067020004

\begin{abstract}
The Jatropha curcas species is a perennial plant and easy to manage, being cultivated in many countries because of its high content in oil and the lowest cost of production. This study had as objective to evaluate the injuries caused by the Pachycoris torridus in J. curcas seedlings. Thirty-four days after the planting, $30 \mathrm{~J}$. curcas seedlings were covered with screens and submitted to herbivory of five bugs of the same sex. Morphological and physiological evaluations were conducted 65 days after planting. Seventy-three days after planting, 24 seedlings were submitted to herbivory, using the same methodology as the previous experiment with a quantitative differential of 10 bugs and a batch of 6 plants without insects (control). Evaluations were done 104 days after planting. Male adults $(\mathrm{n}=5)$ of the $P$. torridus species caused a reduction in the growth and biomass increase in J. curcas seedlings 34 days after planting. After 30 days of herbivores, however the same injuries were not observed in seedlings with 73 days after planting. The injuries (34 days after planting) were considered mild and there was a decrease in the growth and in the biomass accumulation. Upon reaching 73 days after planting, the seedlings became more resistant to the attack of this pest, in such a way that as submitting them to twice the number of insects $(n=10)$, they did not negatively responded to the herbivory. Finally, the young seedlings were more susceptible to attack, even with low levels of infestation. The pest control should be done when there are signs of infestation at this stage.
\end{abstract}

Keywords: bug of the Jatropha; plant growth; photochemical efficiency; accumulation of biomass.

\section{INTRODUCTION}

The species Jatropha curcas, a culture evaluated in this study, is considered a kind of multiple applicability in the cosmetic and pharmaceutical industry, being also a source of biofuel. Oilseeds contain multi-use oil, besides being rich in carbohydrates and used for the production of bioethanol by insecticide fermentation. The seeds constitute $61 \%$ of the fruits, being widely used in obtaining anti-inflammatory drugs. Dyes and tannins, used to dye dark blue and treat leather are obtained from its bark (Cordero et al., 2003; Debnath \& Bisen, 2008; Karaj \& Müller, 2010).
The presence of Pachycoris torridus was observed in several localities in Brazil. In São Paulo (municipality of Piracicaba), during april 2001, it was found feeding on acerola fruits (Sánchez-Soto \& Nakano, 2002); in Minas Gerais, between June 2004 and May 2005, the pest was present in the entire plantation of J. curcas (Saturnino et al., 2005). In addition, in the meek pine tree germplasm bank of the Federal University of Lavras, in December to May the plague remained in the plantation (Avelar \& Quintiliano, 2007). In Rio Largo, municipality of Alagoas, in the cultivation of genotypes aged 28 months, in third fruiting (July, 2008) P torridus were observed damaging leaves and fruits in all $J$ curcas plants, such injuries were

\footnotetext{
Submitted on October $09^{\text {th }}, 2018$ and accepted on January $05^{\text {th }}, 2020$.

${ }^{1}$ This work is part of the first author's doctoral thesis.

Universidade Federal de Alagoas, Faculdade de Medicina, Maceió, Alagoas, Brazil. deadoutorado@hotmail.com

${ }^{3}$ Universidade Estadual de Alagoas, Departamento de Química, Palmeira dos Índios, Alagoas, Brazil. edjanevp@gmail.com;

${ }^{4}$ Universidade Federal de Alagoas, Centro de Ciências Agrárias, Maceió, Alagoas, Brazil. lauricioendres@hotmail.com; fabioluizf@yahoo.com.br; paulovanderleiferreira@bol.com.br

${ }^{5}$ Universidade Federal de Alagoas, Instituto de Química e Biotecnologia, Maceió, Alagoas, Brazil. juan.ramos@iqb.ufal.br

*Autora para correspondência: deadoutorado@hotmail.com
} 
found by chlorosis, necrosis and fall of leaves and fruits. Nymphs and adults were present in all strata of the plant, predominantly in the upper part, close to the fruits (Broglio-Micheletti et al., 2010).

It was observed in the plantation of J. curcas, located in the Center of Agrarian Sciences of the Federal University of Alagoas, $P$ torridus performing phytophygia in leaves and fruits, petiole, stem and aerial parts in all $J$ curcas plants. Therefore, we felt the need to evaluate the severity of injuries caused by $P$. torridus in seedlings of $J$. curcas, in order to implement integrated management tactics in the early stages of this culture, since in the absence of fruits it is common to find such bedbugs performing phytophagia on leaves of this species. In addition, the seedlings of $J$. curcas serve as a natural diet for this species of bedbug, when created in laboratories, and the study of injuries suffered by these seedlings contributes to determine the amount of insects that should be placed in each seedling and the time it needs to be replaced.

The present work evaluated the injuries caused by $P$. torridus in seedlings of $J$. curcas, in order to implement management tactics integrated in the initial stages of this culture, since in the absence of fruits it is common to find such bedbugs performing physophyagy in leaves, petioles, stem and aerial parts of this crop.

\section{MATERIAL AND METHODS}

The injuries caused by $P$. torridus in seedlings of $J$. curcas were evaluated in two models. We chose to use the same different seedlings and insects of the same species to simulate reality, since $J$. curcas in the field suffers injuries in several days after planting. There was homogeneity in the environmental conditions where the experiments were carried out. However, the environment was not fully controlled, since it was not possible to control the abiotic factors (light, temperature and humidity).

(1) Conducted in Galpão (09²8’02"S; 3549’43"W), located in the Center for Agrarian Sciences of the Federal University of Alagoas (CECA/UFAL), in the municipality of Rio Largo, Alagoas, from September to October 2013. The planting of seeds in seedling production $(n=45)$ was carried out with $100 \%$ substrate $(50 \%$ earth, $25 \%$ pie and $25 \%$ coconut fiber) provided by the Plant Genetic Improvement Program (PMGCA), using three J. curcas seeds per vessel $(500 \mathrm{~mL})$. Irrigations were carried out daily at 4 p.m., with $200 \mathrm{ml}$ of water per seedling. After seedling emergence, thinning was performed leaving only one seedling per pot. At 34 days after planting (DAP) the seedlings $(n=45)$ were covered, alone, with anti-amphidic screens, for sealing the entry of other pests and exit from pests under study, as well as to minimize the influence of biotic factors and then submitted to herbivory (15 seedlings with males, 15 seedlings with females) of five bedbugs of the species P. torridus, totaling 150 insects, 15 seedlings served as control. At 65 DAP, gas exchange measurements and photochemical efficiency were measured. The Fully Randomized Design (IHD) was used, with three treatments (Males, Females and Control) and 15 replications;

(2) Conducted in a farm $\left(09^{\circ} 35^{\prime} 03^{\prime \prime} \mathrm{S} ; 35^{\circ} 47^{\prime} 14^{\prime \prime} \mathrm{W}\right)$, in the municipality of Maceió-AL, from October to December 2013. This site was chosen to facilitate the daily management of insects by the researchers involved with the research, since in this place was located the creation of P. torridus in cages (BugDorm-43030 Insect Cage BD43030). Unlike the laboratory, at this site the insects were reproducing more easily and completing their life cycle. The seedlings $(n=30)$ of the model experiment (1) were carefully transported to avoid stress, in their containers within polyvinyl (PVC) boxes and kept in cages (same model of the cages of the creation of P. torridus) with anti-aphidic screen, without insects, where they remained for eight days to recover from the injuries caused by the herbivory of P. torridus. The cages were outdoors supported on wooden planks. At 73 DAP, 24 seedlings of the 30 used in the first experiment were covered, alone, with antiaphidic screens, for sealing the entry of other pests and exiting the pests under study, as in the previous experiment, and inserted in each of them ten bedbugs (ten males, ten females, five males with five females) totaling 180 adult insects and a batch of six plants without insects (control). The evaluations were performed at 104 DAP. The Fully Randomized Design (IHD), composed of four treatments (ten males, ten females, five males with five females and control/without insect), with six replications, was used.

\section{Variables analyzed}

\section{Photochemical Efficiency}

The first fully expanded leaf of each plant (in vivo) was used for the measurements of photochemical efficiency at 65 DAP (Experiment 1) and 104 DAP (Experiment 2). The maximum quantum efficiency ( $\mathrm{Fv} / \mathrm{Fm}$ ) of photosystem II (PSII) was measured at midday. The effective quantum efficiency of photosystem II (ÖPSII) was measured at $1 \mathrm{pm}$ and quantified in vivo with a WALZ-PAM-2500 model portable fluorometer, which employs light pulse amplitude modulation (PAM) -Modulation) to promote the closure of PSII reaction centers according to the method described by Maxwell \& Johnson (2000), with Fv/Fm measured after dark conditioning with plastic tweezers for 20 minutes in a total of one reading per plant. The ÖPSII was measured between 11 and 12 hours on the same sheets as the PSII 
(Fv/Fm) maximum quantum efficiency measurements, according to Schreiber et al, (1995), with two readings per plant.

\section{Gas Exchange}

The measurements of gas exchange were also obtained from the first completely expanded leaf of each plant, at 65 DAP (Experiment 1), between the times of 10 and 12 hours of the morning, performing only one reading per plant. A portable INFRARED $\mathrm{CO}_{2}$ analyzer (IRGA) from LI-COR ${ }^{\circledR}$ model LI-6400XT was used, whose parameters evaluated were: photosynthesis (A), stomatal conductance (gs), transpiration $(\mathrm{E})$, internal concentration of $\mathrm{CO}_{2}(\mathrm{Ci})$. Through the values obtained for these parameters, the efficiency of water use (USA), instantaneous efficiency of carboxylation (EC) and intrinsic efficiency in water use (EIUA) was calculated.

\section{SPAD index and growth analysis (phenology)}

The chlorophyll content of the jatropha leaves was estimated in vivo with a portable chlorophyll meter, model SPAD-502 (Minolta, Japan), at 65 DAP (Experiment 1) and 104 DAP (Experiment 2). Ten random readings of the first fully expanded leaf of each plant were performed. After obtaining these measures began the preparation of material for obtaining data of leaf area, height $(\mathrm{cm})$ and diameter.

\section{Weighing and obtaining of dry mass}

At 65 DAP (Experiment 1) and 104 DAP (Experiment 2) the leaves, petioles, stems and roots were collected for weighing and obtaining the dry mass. Afterwards, the plant material was subjected to drying in a forced air circulation oven, until constant weight, at $65^{\circ} \mathrm{C}$ to obtain the dry mass.

\section{Statistical analysis}

The variables were analyzed by variance analysis, mean (Tukey test) at 5\% probability. The software used was Sisvar - version 5.4 (Ferreira, 2008).

\section{RESULTS AND DISCUSSION}

The data of the maximum quantum efficiency (Fv/Fm) and effective quantum efficiency (ФPSII) are shown in Table

Table 1: Comparison of photochemical efficiency averages (maximum quantum efficiency (Fv / Fm afternoon) and effective quantum efficiency (ÖPSII))

\begin{tabular}{lcc}
\hline Treatment & Fv/Fm afternoon & ФPSII \\
\hline Control & $0,63 \mathrm{a}$ & $0,46 \mathrm{~b}$ \\
5 Females (F) & $0,66 \mathrm{a}$ & $0,54 \mathrm{a}$ \\
5 Males (M) & $0,67 \mathrm{a}$ & $0,49 \mathrm{a} \mathrm{b}$ \\
\hline C.V.\% & 9,45 & 13,86 \\
\hline
\end{tabular}

Note: in the columns, the means with the same letter do not differ among themselves by the Tukey test at $5 \%$ probability.
7. The Fv/Fm of leaves of J. curcas was not influenced by the presence of the insects according to Table 1 . The plants in contact with $P$. torridus (females) had an increase of $17.39 \%$ in the effective quantum efficiency (ÖPSII), while an intermediate increment of $6.52 \%$ was observed in the plants with treatment of the male insects.

The reduction of maximum quantum efficiencies (Fv/ Fm) evaluates the intensity of photoinhibition, when biotic or abiotic factors alter the functionality of photosystem II. A photosynthetic damage can be accused from values of Fv/Fm lower than the parameters of normality (0.75$0.85)$, in response to several types of stresses, among them: pest attacks, mechanical injuries, water stress and saline, herbicide application (Ogren \& Oquist, 1985; Krause \& Weis, 1991; Maxwell \& Johnson, 2000; Baker \& Rosenqvist, 2004; Kocheva et al., 2004; Catunda et al., 2005; Zanandre et al., 2006; Marenco et al., 2007; Liang et al., 2007; Tatagiba \& Pezzopane, 2007; Trovão et al., 2007; Santos, 2008).

Although the values of the maximum quantum efficiency (Fv/Fm afternoon) of photosystem II (PSII) were below the parameters of normality presented in the literature, afternoon Fv/Fm of $J$. curcas seedlings under $P$. torridus herbivory did not differ statistically of the control, in this aspect, which was not subjected to any type of stress. In relation to the effective quantum efficiency ( $\Phi P S I I)$, five females, after 30 days of phytophagy increased the photosynthetic capacity of the seedlings of J. curcas. However, Fv/Fm indicates whether there is any inhibitory damage. In the analysis of this study, it was not observed variation in this variable.

The data of gas exchange, net assimilation of $\mathrm{CO}_{2}(\mathrm{~A})$, stomatal conductance (Gs), transpiration (E), internal concentration of $\mathrm{CO}_{2}(\mathrm{Ci})$, water use efficiency (EUA), instantaneous carboxylation efficiency (EC) and efficiency in water use (EIUA) were not influenced by the treatments, according to Table 2.

Environmental factors, such as pest attack, are perceived by guard cells and these signals are integrated into well-defined stomatal responses. Therefore, in the majority of plants, in a negative response to these factors, they close their stomata to reduce the loss of water by transpiration, since the stomata in the transpiration process $(\mathrm{E})$ control the diffusion of $\mathrm{CO}_{2}$ into the interior of the leaves and the diffusion of water vapor out of the leaves. This causes a decrease in stomatal conductance (gs), lower carbon assimilation and decrease in the rate of photosynthesis (Costa et al., 2001; Taiz \& Zeiger, 2004; Santos, 2008). From the data presented in Table 2, the herbivory performed by five adult female and male bedbugs in a period of 30 days did not produce a negative stomatal response, consequently, there was no change in transpiration and photosynthesis ( $\mathrm{CO}_{2}$ assimilation). 
The height of the plant decreased as a function of the presence of female and male adult insects in $12.25 \%$ and $19.55 \%$, respectively. The diameter also reduced $7.35 \%$ in the presence of females and males. The leaf area had a decrease of $2.14 \%$ in herbivory plants of females and $18.75 \%$ of males.

The height, diameter and leaf area of the plants were negatively affected by the herbivory of $P$. torridus (Table 3 ), and the males caused a greater damage in the plants compared to the females, which can be observed by the smaller height and leaf area when the plants were attacked by males in relation to plants attacked by females. There was no effect of herbivory on the leaf SPAD index.

It was possible to observe that males and females of the species were able to decelerate growth (height, stem thickness and leaf area) of the $J$. curcas seedlings, with males being the most responsible for growth damage.

The development of plants is related to all the changes that occur during their life cycle, whether qualitative (differentiation) or quantitative (growth). Growth involves increased size and / or weight (Cairo et al., 2008). Both depend on extrinsic (environmental) and intrinsic factors (hormonal balance and its genetic potential). Since this study evaluated only the initial stage of J. curcas and not all of its life cycle, the analyzed variables measured growth impairment and not the development of this plant under $P$. torridus herbivory.

The analysis of the SPAD index showed that this pest did not interfere in the chlorophyll content of J. curcas seedlings. The leaf dry mass decreased $10.17 \%$ in the plants that were attacked by males. The dry mass of the stem was greater $6,99 \%$ in the treatment with the females, not significantly different from the control and inferior $13,24 \%$ in the plants submitted to the confinement of ma- les. Female and male treatments had a positive effect on the root variable, with $22.35 \%$ and $3.53 \%$, respectively, however there was no difference between male and control treatments. The total dry mass of the evaluated plants reduced $9.52 \%$ in the treatment with males and increased $6.30 \%$ in the treatment with females, according to Table 4.

The dry mass accumulated by the plant during the photosynthesis process corresponds to $90 \%$, while the remaining $10 \%$ comes from the absorption of mineral nutrients from the soil (Machado et al., 1982). Based on these plant growth data, it is understood that J. curcas, during the experiment, was in the initial phase (slow growth) and that part of the biomass acquired was obtained from the photosynthesis process, which was not compromised with the herbivory of $P$. torridus leading to believe that this pest, mainly males, can remove from the plant the nutrients absorbed from the soil.

The dry matter produced by the plants allows to evaluate the transformation of light energy into chemical energy through the variations of the dimensions of plant parts (leaf, petiole, root and stem), so that the males of the study species were able to reduce the biomass leaves, petiole and stem.

In contrast to smaller plants, herbivory with bedbugs for 30 days did not affect $\quad$ Fv/Fm and ÖPSII and SPAD (Table 5) and stem, petiole and root length, as well as the number of leaves (Table 6) of larger seedlings of $J$. curcas, with 73 DAP.

The fresh and dry matter (Table 7) produced by the plants submitted to the herbivory of bedbugs $(n=10)$ during 30 days (methodology 2), after 73 DAP had no effect between the treatments (seedlings with 10 males, seedlings with 10 females, seedlings with 5 males and 5 females, seedlings without bedbugs). In this study, it was

Table 2: Gaseous exchanges (net assimilation of $\mathrm{CO}_{2}(\mathrm{~A})$, stomatal conductance (Gs), transpiration (E), internal concentration of $\mathrm{CO}_{2}(\mathrm{Ci})$, water use efficiency (EUA), instantaneous carboxylation efficiency (EC) and intrinsic efficiency in the use of water (EIUA)

\begin{tabular}{lccccccc}
\hline Treatment & $\mathbf{A}$ & Gs & $\mathbf{E}$ & $\mathbf{C i}$ & $\mathbf{E U A}$ & $\mathbf{E C}$ & EIUA \\
\hline Control & $11,50 \mathrm{a}$ & $0,19 \mathrm{a}$ & $2,47 \mathrm{a}$ & $235,09 \mathrm{a}$ & $4,99 \mathrm{a}$ & $0,05 \mathrm{a}$ & $69,95 \mathrm{a}$ \\
Females & $11,09 \mathrm{a}$ & $0,19 \mathrm{a}$ & $2,61 \mathrm{a}$ & $233,95 \mathrm{a}$ & $4,46 \mathrm{a}$ & $0,05 \mathrm{a}$ & $63,38 \mathrm{a}$ \\
Males & $11,43 \mathrm{a}$ & $0,19 \mathrm{a}$ & $2,53 \mathrm{a}$ & $227,73 \mathrm{a}$ & $4,84 \mathrm{a}$ & $0,05 \mathrm{a}$ & $69,29 \mathrm{a}$ \\
\hline C.V.\% & 9,85 & 37,39 & 27,18 & 13,04 & 27,06 & 13,52 & 34,92 \\
\hline
\end{tabular}

Note: in the columns, the means with the same letter do not differ by the Tukey test at $5 \%$ probability.

Table 3: Height, diameter, leaf area and SPAD index of J. curcas under herbivory of P. torridus

\begin{tabular}{lcccc}
\hline Treatment & Height & Diameter & Leaf area & SPAD \\
\hline Control & $27,01 \mathrm{a}$ & $1,36 \mathrm{a}$ & $813,55 \mathrm{a}$ & $31,61 \mathrm{a}$ \\
Plant with 5 Females & $23,70 \mathrm{~b}$ & $1,26 \mathrm{~b}$ & $796,17 \mathrm{~b}$ & $32,80 \mathrm{a}$ \\
Plant with 5 Males & $21,73 \mathrm{c}$ & $1,26 \mathrm{~b}$ & $660,97 \mathrm{c}$ & $32,35 \mathrm{a}$ \\
\hline C.V.\% & 8,72 & 4,55 & 7,01 & 9,08 \\
\hline
\end{tabular}

Note: in the columns, the means with the same letter do not differ by the Tukey test at 5\% probability. 
observed that as they developed (73 DAP) they became more resistant to $P$. torridus attack, since when they received twice the number of insects $(n=10)$ they did not show any difference between the treatments when compared to the control, so this phase of the plants can be used, due to the resistance of the molt, as a natural diet of $P$. torridus in the laboratory.

With 34 DAP and herbivory of bedbugs $(n=5)$, for 30 days (Method 1), there were injuries. However, they were mild and limited to the growth and accumulation of biomass when compared to the control.

In sum, the seedlings that suffered injuries were in the period from 34 to 64 DAP, being infested by 5 bedbugs, and the seedlings submitted to the herbivory of 10 bedbugs, in the period from 73 to 103 DAP, did not suffer injuries. It is possible in the lack of fruit or leaves of adult plants of J. curcas or P. torridus to perform herbivory on seedlings of $J$. curcas and cause damage, as the phytophagy carried out by these bedbugs is varied (various parts of plants) and intense, once they were found in the field, with the rostrum stilettos inserted in the leaves, aerial parts and petioles, performing phytophagy around two consecutive hours.

Pachycoris torridus has a sucking mouthpiece from its early stages (nymphs), which develops when reaching adulthood, to the point of sucking any part of the plant, however its most preferred at this stage (adult) is the green or ripe fruit. (Brittaine \& Lutaladio, 2010; Nava \& Delmar, 2009; Broglio-Micheletti et al., 2010; Rodrigues et al., 2011).

Another issue observed was the resistance that $J$. curcas had to the attack of $P$. torridus, even in the early stages. As the seedlings of this species serve as a diet for the studied pest, kept in insecticide, then, it is suggested to use seedlings with more than 73 DAP for the resistance shown to the attack of this pest, prolonging the replacement period of the seedlings submitted to herbivory.

The findings of Rodrigues et al. (2011) and Grimm (1999) place females as responsible for injuries caused to the fruits and seeds of Jatropha curcas, because the fruits that received a male little reduced mass, not differing from fruits without bedbugs. According to these authors, females need to acquire nutritional reserves for egg development, because after laying, they keep protecting eggs and nymphs (up to 2nd instar), thus needing acquired reserves. Grimm (1999) also found that males of the species Pachycoris klugii did not reduce the mass of jatroph-jase fruits, the greatest damage caused by nymphs and females. While, in the present study, males were the biggest cause of damage. However, in this study, injuries caused in seedlings were evaluated and previous studies were carried out with the fruit, which may be the part of the plant essential for the maintenance and survival of females, since they require caloric reserves to remain alive in the period of oviposition and custody of postures.

It is worth remembering that males are smaller when compared to females, have approximately half of their weight, are more agile and, when undergoing high stress situations (evaluation of work performed by the authors of this article, but that they have not yet continue to perform intense herbivory, while females retreat and isolate themselves. With this, the new confinement environment may have contributed to females reducing their food disposition. Gabriel \& Franco (2012), during observations

Table 4: Comparison of dry mass of leaf, petiole, stem, root and total dry mass of plants submitted to herbivory by $P$. torridus and control (change without insects)

\begin{tabular}{lccccc}
\hline Treatment & Leaf & Petiole & Stem & Root & MST \\
\hline Control & $2,36 \mathrm{a}$ & $0,90 \mathrm{a}$ & $2,72 \mathrm{a}$ & $0,85 \mathrm{~b}$ & $6,83 \mathrm{~b}$ \\
Plan with 5 Females & $2,33 \mathrm{a} \mathrm{b}$ & $0,98 \mathrm{a}$ & $2,91 \mathrm{a}$ & $1,04 \mathrm{a}$ & $7,26 \mathrm{a}$ \\
Plan with 5 Males & $2,12 \mathrm{~b}$ & $0,82 \mathrm{~b}$ & $2,36 \mathrm{~b}$ & $0,88 \mathrm{~b}$ & $6,18 \mathrm{c}$ \\
\hline C.V.\% & 11,63 & 10,76 & 11,64 & 18,60 & 7,00 \\
\hline
\end{tabular}

Note: in the columns, the means with the same letter do not differ by the Tukey test at $5 \%$ probability.

Table 5: Mean of FM-FM dawn, FV-FM afternoon, YIELD and SPAD of plants submitted to herbivory of $P$. torridus and control (changes without insects)

\begin{tabular}{|c|c|c|c|c|}
\hline Treatment & FV-FM dawn & FV-FM & YIELD afternoon & SPAD \\
\hline Plant with $10 \mathrm{M}$ & $0,79417 \mathrm{a}$ & $0,61333 \mathrm{a}$ & $0,48200 \mathrm{a}$ & $28,65000 \mathrm{a}$ \\
\hline Plant with $10 \quad \mathrm{~F}$ & $0,78817 \mathrm{a}$ & 0,54233 a & $0,51650 \mathrm{a}$ & 27,18333 a \\
\hline Plant with $5 \mathrm{M}+5 \mathrm{~F}$ & $0,79133 \mathrm{a}$ & $0,63267 \mathrm{a}$ & $0,52750 \mathrm{a}$ & $25,75000 \mathrm{a}$ \\
\hline Control (plant without insect) & 0,78467 a & 0,58917 a & $0,51617 \mathrm{a}$ & $27,63333 \mathrm{a}$ \\
\hline C.V.\% & 2,03 & 14,00 & 13,84 & 10,47 \\
\hline
\end{tabular}

Note: in the columns, the means with the same letter do not differ by the Tukey test at 5\% probability. 
Tables 6: Mean of stem length, petiole, root, and number of leaves of plants submitted to herbivory and control (changes without insects)

\begin{tabular}{lcccc}
\hline Treatment & $\begin{array}{c}\text { Length stalk } \\
\text { after herbivory }\end{array}$ & $\begin{array}{c}\text { Length petiole } \\
\text { after herbivory }\end{array}$ & $\begin{array}{c}\text { Root length } \\
\text { after herbovory }\end{array}$ & $\begin{array}{c}\text { Number } \\
\text { of leaves }\end{array}$ \\
\hline Plant with 10 M & $13,22 \mathrm{a}$ & $50,84 \mathrm{a}$ & $15,66 \mathrm{a}$ & $23,59 \mathrm{a}$ \\
Plant with 10 F & $14,58 \mathrm{a}$ & $57,10 \mathrm{a}$ & $14,34 \mathrm{a}$ & $27,10 \mathrm{a}$ \\
Plant with 5M+5F & $16,02 \mathrm{a}$ & $57,94 \mathrm{a}$ & $13,32 \mathrm{a}$ & $32,13 \mathrm{a}$ \\
Control (plant without insect) & $15,36 \mathrm{a}$ & $49,00 \mathrm{a}$ & $14,88 \mathrm{a}$ & $28,29 \mathrm{a}$ \\
\hline C.V.\% & 11,76 & 17,32 & 15,80 & 22,71 \\
\hline
\end{tabular}

Note: in the columns, the means with the same letter do not differ by the Tukey test at $5 \%$ probability.

Table 7: Mean of fresh mass, leaf dry mass, root + stem + petiole and total of herbivory and control plants (without insects)

\begin{tabular}{lcccc}
\hline Treatment & $\begin{array}{c}\text { Mass fresh } \\
\text { (sheet) }\end{array}$ & $\begin{array}{c}\text { Mass dry } \\
\text { (root + stem + petiole) }\end{array}$ & $\begin{array}{c}\text { Mass dry } \\
\text { Total }\end{array}$ & $\begin{array}{c}\text { Massa dry } \\
\text { after herbivory }\end{array}$ \\
\hline Plant with 10 M & $5,00 \mathrm{a}$ & $1,06 \mathrm{a}$ & $3,26 \mathrm{a}$ & $4,33 \mathrm{a}$ \\
Plant with 10 F & $5,20 \mathrm{a}$ & $0,94 \mathrm{a}$ & $4,59 \mathrm{a}$ & $5,50 \mathrm{a}$ \\
Plant with 5M+5F & $5,60 \mathrm{a}$ & $1,23 \mathrm{a}$ & $4,61 \mathrm{a}$ & $5,81 \mathrm{a}$ \\
Control (plant without insect) & $5,00 \mathrm{a}$ & $1,08 \mathrm{a}$ & $4,15 \mathrm{a}$ & $5,23 \mathrm{a}$ \\
\hline C.V.\% & 9,62 & 22,48 & 30,91 & 27,62 \\
\hline
\end{tabular}

Note: in the columns, the means with the same letter do not differ by the Tukey test at $5 \%$ probability.

verified the preference of adults for protection and dark habitats, as they hid frequently. Grimm \& Somarriba (1998) observed similar behavior in P. klugii in J. curcas's herbivory.

\section{CONCLUSION}

Male adults of the species Pachycoris torridus caused injuries to jatropha curcas seedlings with 34 DAP, after 30 days of herbivory. Injuries affected biomass growth and accumulation. There was a impairment of height, leaf ing area, petiole and stem of plants that were submitted to male herbivory in experiment I. Therefore, pest control should be done when signs of infestation occur at this stage. However, it is not yet known whether these injuries will compromise oil production, and it is necessary to evaluate these plants when they reach adulthood and produce fruits. On the other hand, by reaching 73 DAP, the seedlings became more resistant to the attack of this pest, even if they were subjected to herbivory with twice as many insects. The species $J$. curcas was resistant to the attack of $P$. torridus, even in the early stages (from 73 DAP). To reduce costs, efforts and save time in the creation of $P$. torridus in the laboratory, it is suggested to use seedlings, of J. curcas in the diet of this bedbug, with more than 73 DAP, by the resistance shown to the attack of this pest, prolonging the period of substitution of seedlings submitted to herbivory. As for planting in the field, it is necessary to transplant them when they reach 73 DAP, as they will be more resistant to $P$. torridus attack.

\section{REFERENCES}

Avelar RC \& Quintiliano AA (2007) Avaliação da ocorrência do percevejo Pachycoris torridus em plantas de pinhão manso do banco de germoplasma da UFLA. In: Congresso da rede brasileira de tecnologia de biodiesel, Brasília. Anais, MCT/ ABIPTI. p.5.

Baker NR \& Rosenqvist E (2004) Applications of chlorophyll fluorescence can improve crop production strategies: an examination of future possibilities. Journal of Experimental Botany, 55:1607-1621.

Brittaine R \& Lutaladio N (2010) Jatropha: A Smallholder Bioenergy Crop. Rome, FAO.114p.

Broglio-Micheletti SMF, Edres L, Valente ECN, Souza LA, Santos CM \& Dias NS (2010) Primeiro registro de Pachycoris torridus (Scopoli, 1772). Ciência e Agrotecnologia, 34:1654-1657.

Cairo PAR, Cairo R, Oliveira LEM \& Mesquita AC (2008) Análise de Crescimento de Plantas. Vitória da Conquista, Edições UESB. $72 \mathrm{p}$.

Catunda MG, Freitas SP, Oliveira JG \& Silva CMM (2005) Efeitos de herbicidas na atividade fotossintética e no crescimento de abacaxi (Ananas comosus). Planta Daninha, 23:115-121.

Cordero J, Boshier D \& Barrance A (2003) Árboles de Centroamérica: un manual para extensionistas. Costa Rica, Centro Agronómico Tropical de Investación Enseñanza. 1080p.

Costa C, Dwyer LM, Dutilleul P, Stewart DW, Ma BL \& Smith DL (2001) Inter-relationships of applied nitrogen, SPAD, and yield of leafy and non-leafy maize genotypes. Journal of Plant Nutrition, 24:1173-1194.

Debnath M \& Bisen P (2008) Jatropha curcas L., a multipurpose stress resistant plant with a potential for ethnomedicine and renewable energy. Current Pharmaceutical Biotechnology, 9:288-306.

Ferreira DF (2008) SISVAR: um programa para análises e ensino de estatística. Revista Symposium, 6:36-41. 
Gabriel D \& Franco DAS (2012) Aspectos biológicos e morfológicos de Pachycoris torridus S copoli , 1772 ( Hemiptera/ : Scutelleridae ) criados com pinhão-manso Jatropha curcas L., 1753, em laboratório. Científica, 40:156-163.

Grimm C (1999) Evaluation of damage to physic nut (Jatropha curcas) by true bugs. Enthomology Experimentalis et Applicata, 92:127-136.

Grimm C \& Somarriba A (1998) Life cycle and rearing of the shield-backed bug Pachycoris klugii in Nicaragua (Heteroptera: Scutelleridae). Entomologia Generalis, 22:211- 221.

Karaj S \& Müller J (2010) Determination of physical, mechanical and chemical properties of seeds and kernels of Jatropha curcas L. Industrial Crops Products, 32:129-38.

Kocheva K, Lambrev P, Georgiev G, Goltsev V \& Karabaliev M (2004) Evaluation of chlorophyll fluorescence and membrane injury in the leaves of barley cultivars under osmotic stress. Bioelectrochemistry, 63:121-124.

Krause GH \& Weis E (1991) Chlorophyll fluorescence and photosynthesis: The basics. Annual Review of Plant Physiology and Plant Molecular Biology, 42:313-349.

Liang Y, Chen H, Tang MJ, Yang PF \& Shenet SH (2007) Responses of Jatropha curcas seedlings to cold stress: photosynthesis related proteins and chlorophyll fluorescence characteristics. Physiologia Plantarum, 131:508-517.

Machado EC, Pereira AR, Fahl JI, Arruda JV \& Cione J (1982) Índices biométricos de duas cultivares de cana-de-açúcar. Pesquisa Agropecuária Brasileira, 17:1323-1329.

Marenco RA, Neves TS, Camargo MSB, Dias DP, Costa GF \& Rodrigues JC (2007) Fotoinibição dinâmica da fotossíntese em árvores de dossel da Amazônia Central. Revista Brasileira de Biociências, 5:150-152.

Maxwell K \& Johnson GN (2000) Chlorophyll fluorescence: a pratical guide. Journal of Experimental Botany, 51:659-668.

Nava DE \& Delmar S (2009) Insetos Praga e Benéficos na Cultura do Tungue. Embrapa Clima Temperado. Pelotas, Embrapa.13p.
Ogren E \& Oquist G (1985) Effect of drought on photosynthesis, chlorophyll florescence and photoinhibition susceptibility in intact willow leaves. Planta, 166:380-388.

Rodrigues SR, De Oliveira HN, Dos Santos YT \& Abotet AR (2011) Aspectos biológicos e danos de Pachycoris torridus em pinhãomanso. Bragantia, 70:356-360.

Sánchez-Soto S \& Nakano O (2002) Ocorrência de Pachycoris torridus (Scopoli) (Hemiptera: Scutel- leridae) em acerola (Malpighia glabra L.) no Brasil. Neotropical Entomology, 31:481-482.

Santos CM (2008) Fenologia e capacidade fotossintética do pinhãomanso (Jatropha curcas L.) em diferentes épocas do ano no estado de Alagoas. Dissertação de Mestrado. Universidade Federal de Alagoas, Rio Largo. 67p.

Saturnino HM, Pacheco DD, Kakida J, Tominaga N \& Gonçalves NP (2005) Cultura do pinhão manso (Jatropha curcas L.). Informe Agropecuário, 26:44-78.

Schreiber U, Hormann H, Neubauer C \& Klughammer C (1995) Assessment of photosystem II photochemical quantum yield by chlorophyll fluorescence quenching analysis. Australian Journal of Plant Physiology, 22:209-220.

Taiz L \& Zeiger E (2004) Fisiologia vegetal. $3^{\text {a }}$ ed. Porto Alegre, Artmed. 719p.

Tatagiba SD \& Pezzopane JEM (2007) Cinética de emissão de fluorescência das clorofilas em dois clones de eucalyptus. Revista Científica Eletrônica de Engenharia Florestal, 10:01-14.

Trovão DMB, Fernandes PD, De Andrade LA \& Neto JD (2007) Variações sazonais de aspectos fisiológicos de espécies da Caatinga. Revista Brasileira de Engenharia Agrícola Ambiental, 11:307-311.

Zanandrea I, Nassi FL, Turchetto AC, Braga EJB, Peters JA \& Bacarin MA (2006) Efeito da salinidade sob parâmetros de fluorescência em Phaseolus vulgaris. Revista Brasileira de Agrociência, 12:157-161. 